\title{
Modulation of Type I Iodothyronine 5'-Deiodinase Activity in white Adipose Tissue by Nutrition: Possible Involvement of Leptin
}

\author{
Z. MACEK JÍLKOVÁ ${ }^{1}$, S. PAVELKA ${ }^{2}$, P. FLACHS ${ }^{1}$, M. HENSLER ${ }^{1}$, V. KŮS ${ }^{1}$, \\ J. KOPECKÝ ${ }^{1}$
}

${ }^{1}$ Department of Adipose Tissue Biology, Institute of Physiology of the Academy of Sciences of the Czech Republic, Prague, Czech Republic, ${ }^{2}$ Department of Radiometry, Institute of Physiology of the Academy of Sciences of the Czech Republic, Prague, Czech Republic

Received July 24, 2009

Accepted September 11, 2009

On-line November 20, 2009

\section{Summary}

Adipose tissue is an important target for thyroid hormones (TH). However, the metabolism of TH in white adipose tissue is poorly characterized. Our objective was to describe possible changes in activities of TH-metabolizing enzymes in white adipose tissue, and the role of $\mathrm{TH}$ metabolism in the tissue during obesogenic treatment, caloric restriction and in response to leptin in mice. Activity of type I iodothyronine $5^{\prime}$-deiodinase (D1) in white fat was stimulated by a high-fat diet, which also increased plasma leptin levels, while brown adipose tissue D1 activity did not change. Caloric restriction decreased the activity of D1 in white fat (but not in the liver), reduced leptin levels, and increased the expression of stearoyl CoA desaturase 1 (SCD-1), a marker and mediator of the effect of leptin on tissue metabolism. Leptin injections increased D1 activity and down-regulated SCD-1 in white fat. Our results demonstrate changes in D1 activity in white adipose tissue under the conditions of changing adiposity, and a stimulatory effect of leptin on D1 activity in the tissue. These results suggest a functional role for D1 in white adipose tissue, with D1 possibly being involved in the control of adipose tissue metabolism and/or accumulation of the tissue.

\section{Key words}

Adipose tissue $\bullet$ Thyroid hormones $\bullet$ Obesity $\bullet$ Caloric restriction - Leptin

\section{Corresponding author}

J. Kopecký, Department of Adipose Tissue Biology, Institute of Physiology of the Academy of Sciences of the Czech Republic, v.v.i., Vídeňská 1083, 14220 Prague 4, Czech Republic. E-mail: kopecky@biomed.cas.cz

\section{Introduction}

The accumulation of body fat could be affected by influencing the capacity of fat cells to proliferate and differentiate, and by the metabolism of adipocytes. Through these mechanisms, hormones, pharmacological agents and nutrients could affect adiposity, suggesting novel therapeutic strategies for obesity treatment (Kopecký et al. 2004, Orci et al. 2004, Růžičková et al. 2004). In this respect, white adipose tissue represents an important target for thyroid hormones (TH) (Oppenheimer et al. 1991, Yen 2001, Obregon 2008), which, together with a sympathetic nervous system, became the most important central regulators of energy balance and thermogenesis in homeothermic animals (Silva 2006). Multiple biological effects of TH depend on intracellular levels of $3,5,3^{\prime}$, - triiodothyronine $\left(\mathrm{T}_{3}\right)$, which binds to thyroid hormone receptor and is for the most part generated in peripheral tissues by outer-ring deiodination of thyroxine $\left(\mathrm{T}_{4}\right)$. Type $\mathrm{I}$ and type II iodothyronine 5'-deiodinase (D1 and D2, respectively) could catalyze the reaction. D1 exerts on a relatively broad substrate specificity, while also catalyzing innerring deiodination of $\mathrm{T}_{4}$ to produce reverse $\mathrm{T}_{3}$, an inactive form of $\mathrm{TH}$, as well as deiodination of other $\mathrm{TH}$ derivatives (Galton et al. 2009). D2 also catalyzes conversion of $\mathrm{T}_{3}$ into 3,3'-diiodothyronine $\left(\mathrm{T}_{2}\right)$. Type III 5-deiodinase (D3), catalyses inner-ring deiodination of $\mathrm{T}_{4}$ and $T_{3}$, to produce reverse $T_{3}$ and $T_{2}$. D1 is mainly present in the liver, kidney, thyroid gland, and pituitary, and due to its high activity, the hepatic D1 is traditionally 
regarded as being an important source of circulating $\mathrm{T}_{3}$; in turn, its activity is increased by circulating $\mathrm{T}_{3}$ (Bianco et al. 2002) and by leptin (Cabanelas et al. 2006, Araujo et al. 2009). However, it has also been suggested that the main role of D1 is to serve as a scavenger enzyme that deiodinates iodothyronines as well as other $\mathrm{TH}$ derivatives in extrathyroid tissues, and recycles iodine within the organism (Galton et al. 2009). D2, which is mainly present in the brain, brown fat, placenta, pituitary, and muscle, is essential to the local generation of $T_{3}$ in the tissues [for references see Pavelka et al. (1997)]. In brown fat, $\mathrm{D} 2$ activity is stimulated by adrenergic nerves in response to leptin (Araujo et al. 2009), it is required for tissue differentiation and thermogenic function (Obregon 2008), and it contributes to systemic $\mathrm{T}_{3}$ levels (Leonard et al. 1983, Kopecký et al. 1986). However, the metabolism of TH in white fat and its possible biological role are poorly described. D3 has been suggested to stimulate the proliferation of white fat cells, while D2 could be linked to the differentiation program of adipocytes, as revealed by in vitro experiments (Obregon 2008). D1 was found in white fat in rats (Leonard et al. 1983) as well as in infants (Pavelka et al. 1997), although its specific activity is very low compared with the liver or kidneys (Pavelka et al. 1997) and D1 function in white fat remains unknown.

Leptin secreted by adipose tissue was identified as an important signaling molecule that affects the activity of hypothalamic centers, while decreasing food intake, activating energy expenditure and modulating neuroendocrine functions. Secretion of leptin increases with adipose tissue hypertrophy (Zhang et al. 1994). However, leptin also acts directly on tissues, where it stimulates fatty acid oxidation, decreases lipogenesis, and prevents the accumulation of lipids in non-adipose tissues, by activating AMP-activated protein kinase (AMPK) (Minokoshi et al. 2002). The enhancement of AMPK activity by leptin is also a part of the mechanism by which leptin induces the transformation of fat-storing white adipocytes into fat-oxidizing cells, and lean phenotype (Orci et al. 2004). As shown in both white fat (Zhang et al. 2008) and the liver (Kakuma et al. 2002, Cohen and Friedman 2004, Biddinger et al. 2006), leptin also down-regulates stearoyl CoA desaturase 1 (SCD-1), a lipogenic gene with a key role in the leptin metabolic action, since the down-regulation of SCD-1 results in stimulation of lipid catabolism (Cohen and Friedman 2004, Paton and Ntambi 2008).

$\mathrm{TH}$ and leptin may share some common downstream action sites and could act additively, although independently, to enhance energy expenditure (Wang et al. 2000). However, especially in white adipose tissue, the possible interplay between TH and leptin in the control of metabolism and weight of the tissue remains to be better characterized. The activities of D1, D2, and D3 were therefore assessed in white adipose tissue of mice under the conditions that promoted either tissue hypertrophy or involution. Only D1 specific activity, which was the highest among all three iodothyronine deiodinase enzymes, showed significant changes in response to obesogenic treatment and correlated with adiposity. The results suggest that leptin controls D1 activity in white fat and that D1 has a functional role in the tissue.

\section{Methods}

\section{Animals and treatments}

C57BL/6J mice were obtained from the Jackson Laboratory (Bar Harbor, ME, USA) and bred at the Institute of Physiology for several generations. Only male mice, caged singly, were used for the experiments. Three different treatment protocols were used, as specified below.

1) Obesogenic treatment: mice born and maintained at $30{ }^{\circ} \mathrm{C}$ were weaned at four weeks of age to either the low-fat (LF) or high-fat (HF) diet. The LF diet (extruded Ssniff R/M-H diet; Ssniff Spezialdieten GmbH, Soest, Germany) contained $25 \%, 9 \%$, and $66 \%$ calories in the form of protein, fat, and carbohydrate, respectively. The HF diet, proven to be obesogenic in C57BL/6J mice, contained $15 \%, 59 \%$, and $26 \%$ calories in the form of protein, fat, and carbohydrate, respectively [for cHF diet see Kuda et al. (2009)]. All the analyses described below were performed two or eight weeks after weaning. For the collection of plasma and tissues, ad libitum-fed mice were killed by cervical dislocation between 9 and 10 a.m. EDTA-plasma was prepared from truncal blood and stored at $-70{ }^{\circ} \mathrm{C}$. Subcutaneous (dorsolumbar) and epididymal white adipose tissue, interscapular brown fat [for adipose tissue nomenclature see Cinti (1999)] and liver were dissected and stored in liquid nitrogen.

2) Caloric restriction: mice born and maintained at $22{ }^{\circ} \mathrm{C}$ were fed the LF diet after weaning (see above) and then fed the HF diet for seven weeks, beginning at the age of three months. During the last five weeks of the HF-feeding, one group of mice was fed ad libitum (HF-AL), while the other group of mice was subjected to $10 \%$ caloric restriction (HF-CR) compared with the 
HF-AL mice. Mice were killed and plasma and epididymal white adipose were collected as above.

3) Leptin treatment: mice born and maintained at $22{ }^{\circ} \mathrm{C}$ were weaned to the LF diet (see above) and, two weeks after weaning, mice were subcutaneously injected with three doses $(3 \mathrm{mg} / \mathrm{kg})$ of recombinant mouse leptin (R\&D Systems, Minneapolis, MN, USA) or saline at 4 p.m. on day 1 , and at 8 a.m. and 4 p.m on day 2. Mice were killed 16 hours after the last injection and epididymal white adipose tissue was collected as above.

All experiments were performed in accordance with the guidelines of the Institute of Physiology for the use and care of laboratory animals, the directive of the European Communities Council (86/609/EEC), and the Principles of Laboratory Animal Care (NIH publication no. 85-23, revised 1985).

\section{Light microscopy and cell-size measurement}

Epididymal and dorsolumbar fat samples were fixed in $10 \%$ neutral buffered formalin (Sigma) and embedded in paraffin. Sections $(5 \mu \mathrm{m})$ were stained with hematoxylin and eosin, and images were captured by an Olympus AX70 light microscope and a DP 70 camera (Olympus, Tokyo, Japan). Morphometry of adipocytes was performed using a Lucia IMAGE version 4.81 morphometric program (Laboratory Imaging, Prague, Czech Republic).

\section{Hormones in plasma}

Leptin concentration was assessed using a Mouse Leptin RIA Kit (Linco Research, St. Charles, MO, USA). Serum total and free $T_{3}$ and $T_{4}$ levels were determined using RIA kits (Immunotech, Beckman Coulter, Czech Republic).

\section{Quantitative RT-PCR}

Transcript levels of the genes for SCD-1 and D1 were evaluated in total RNA isolated from the epididymal adipose tissue and normalized using eukaryotic translation elongation factor 2 measured as described previously (Kuda et al. 2009). The primers used: 5'-CCGCCAAGCAGAGGGTCAC-3' and 5'-GCATTC AGGGCTAACATCCAACT-3' for leptin; 5'-ACTGGG GCTGCTAATCTCTGGGTGTA-3' and 5'-GGCTTTAT CTCTGGGGTGGGTTTGTTA-3' for SCD-1; 5'-CTGT GGCGTGAGCTTCTTC-3' and 5'-CCCCTGGTGTTG AACTTTG-3' for D1; and 5'-GAAACGCGCAGATG TCCAAAAGTC-3' and 5'-GCCGGGCTGCAAGTC TAAGG-3' for eukaryotic translation elongation factor 2 .
Assay of activity of iodothyronine deiodinases

Activities of D1, D2, and D3 were measured as previously described (Pavelka et al. 1997). The activities were determined in microsomal (liver) or submitochondrial supernatant (adipose tissue) fractions prepared from frozen tissue samples using 2-200 $\mu \mathrm{g}$ of total protein (depending on the type of tissue) in a final volume of $40 \mu \mathrm{l}$. Radioactive products ${ }^{125} \mathrm{I}$-iodide ${ }^{125} \mathrm{I}_{-} \mathrm{T}_{2}$ and ${ }^{125}$ I-reverse $\mathrm{T}_{3}$ (and non-radioactive $\mathrm{I}^{-}$) were separated from the unconsumed radioactive substrates $\left({ }^{125} \mathrm{I}\right.$-reverse $\mathrm{T}_{3},{ }^{125} \mathrm{I}_{-} \mathrm{T}_{4}$, and ${ }^{125} \mathrm{I}-\mathrm{T}_{3}$ ) by thin layer chromatography. The radiochromatograms were evaluated using the BAS-5000 laser scanner (Fujifilm Co., Japan). Specific enzyme activities were expressed as picomoles of respective iodothyronine produced per hour per mg of protein.

\section{Statistics}

Statistical analyses of the data were performed, and the probability values $\mathrm{p}$ for significance were calculated by Student's t-test. Relationships between D1 activity in adipose tissue and (i) size of adipocytes or (ii) plasma leptin levels were assessed using Pearson's correlation coefficient. All values are expressed as mean \pm S.E.M.

\section{Results}

\section{Obesogenic treatment}

To evaluate possible changes in activities of iodothyronine deiodinases in adipose tissue in response to the tissue expansion, the effect of HF diet feeding, which is known to induce obesity in C57BL/6J mice (Surwit et al. 1995), was evaluated. Mice were born and maintained at $30{ }^{\circ} \mathrm{C}$ during the experiment to avoid any influence of cold stress on the measured parameters, and weaned to either the LF or HF diet. Mice were killed two and eight weeks after weaning (Table 1). Even after eight weeks, only body weight gain but not body weight, was significantly higher in the HF-diet group. However, already after two weeks, the weights of both epididymal (visceral) and dorsolumbar (subcutaneous) fat depots were significantly higher in the HF-diet group, as compared with the LF diet-fed mice $(\sim 1.5$ - and $\sim 1$.4-fold, respectively). After eight weeks, the differences became more pronounced, with a stronger effect on epididymal fat ( 2.9-fold higher weight of the depot in the HF dietfed mice). In line with a previous study, HF diet feeding resulted in a decrease of interscapular brown fat weight (Kůs et al. 2008). As revealed by histological analysis, 
Table 1. Growth characteristics, adiposity, plasma levels of hormones and D1 activity - obesogenic treatment.

\begin{tabular}{|c|c|c|c|c|}
\hline & \multicolumn{2}{|c|}{2 weeks } & \multicolumn{2}{|c|}{8 weeks } \\
\hline & $\mathbf{L F}$ & HF & $\mathbf{L F}$ & HF \\
\hline \multicolumn{5}{|l|}{ Body weight (g) } \\
\hline Initial & $17.5 \pm 0.7$ & $17.3 \pm 0.5$ & $17.8 \pm 0.8$ & $18.0 \pm 0.9$ \\
\hline Final & $20.8 \pm 0.3$ & $20.7 \pm 0.4$ & $26.8 \pm 1.0$ & $31.2 \pm 2.3$ \\
\hline Gain & $3.3 \pm 0.4$ & $3.4 \pm 0.6$ & $9.0 \pm 0.7$ & $13.2 \pm 1.5^{*}$ \\
\hline \multicolumn{5}{|c|}{ Weight of fat depots (mg) } \\
\hline$E P I$ & $242 \pm 13$ & $366 \pm 22 * *$ & $447 \pm 63$ & $1311 \pm 320^{* *}$ \\
\hline$D L$ & $143 \pm 4$ & $200 \pm 7^{* *}$ & $180 \pm 13$ & $442 \pm 80 * *$ \\
\hline$B A T$ & $105 \pm 5$ & $71 \pm 3^{* *}$ & $154 \pm 8$ & $137 \pm 15$ \\
\hline \multicolumn{5}{|c|}{ Adipocytes surface area $\left(\mu m^{2}\right)$} \\
\hline$E P I$ & $3505 \pm 115$ & $4779 \pm 292 *$ & $3120 \pm 392$ & $5739 \pm 973^{*}$ \\
\hline$D L$ & $1993 \pm 317$ & $3029 \pm 105^{*}$ & $2126 \pm 572$ & $4794 \pm 575^{*}$ \\
\hline \multicolumn{5}{|l|}{ Plasma levels } \\
\hline Leptin $(n g / m l)$ & $3.9 \pm 0.4$ & $6.2 \pm 0.4^{* *}$ & $5.6 \pm 1.3$ & $27.6 \pm 6.7^{* *}$ \\
\hline total $T_{4}(\mathrm{nmol} / \mathrm{l})$ & $36.9 \pm 0.8$ & $41.6 \pm 1.1 * *$ & $62.8 \pm 4.0$ & $62.9 \pm 1.4$ \\
\hline total $T_{3}(\mathrm{nmol} / \mathrm{l})$ & $0.96 \pm 0.03$ & $1.30 \pm 0.03 * *$ & $0.71 \pm 0.05$ & $1.07 \pm 0.05 * *$ \\
\hline free $T_{4}(\mathrm{pmol} / \mathrm{l})$ & $13.8 \pm 0.6$ & $13.2 \pm 0.9$ & $12.2 \pm 0.8$ & $11.3 \pm 0.6$ \\
\hline free $T_{3}(\mathrm{pmol} / \mathrm{l})$ & $5.23 \pm 0.54$ & $4.90 \pm 0.40$ & $4.40 \pm 0.55$ & $4.21 \pm 0.58$ \\
\hline \multicolumn{5}{|c|}{ D1 activity (pmol $T_{2} / h / m g$ protein) } \\
\hline$E P I$ & $5.6 \pm 0.5$ & $6.0 \pm 1.0$ & $3.5 \pm 1.9$ & $12.0 \pm 1.1^{*}$ \\
\hline$D L$ & $2.2 \pm 0.3$ & $3.8 \pm 0.6^{*}$ & $6.5 \pm 0.5$ & $11.2 \pm 1.3^{*}$ \\
\hline$B A T$ & $2.0 \pm 0.3$ & $2.1 \pm 0.3$ & $0.9 \pm 0.2$ & $0.8 \pm 0.3$ \\
\hline Liver & $1288 \pm 87$ & $2178 \pm 153^{* *}$ & $877 \pm 144$ & $2364 \pm 444^{*}$ \\
\hline
\end{tabular}

Mice weaned at four weeks after birth to low-fat (LF) or a high-fat (HF) diet were analyzed after two $(n=18)$ and eight weeks $(n=7-9)$, following the obesogenic treatment protocol. Mice were born and maintained at $30^{\circ} \mathrm{C}$. EPI - epididymal white fat, $D L-$ dorsolumbar white fat, $B A T$ - interscapular brown fat. The morphometry data are based on $>2400$ cells taken randomly from six different areas per animal $(n=3-4)$. Activity of $D 1$ ( $p m o l T_{2} / h / m g$ protein) was evaluated after two $(n=14-17)$ and eight $(n=3-8)$ weeks. Data are means \pm S.E.M. $* p<0.05 ; * * p<0.005$ for the effect of diet.

the size of adipocytes in both white fat depots also increased in response to the HF diet, the most pronounced effect being in epididymal fat after eight weeks (Table 1). Plasma concentration of leptin increased significantly after two weeks of HF feeding, and after eight weeks, leptin levels were even more profoundly elevated. While there were no differences between the LF and HF groups in plasma levels of free $T_{4}$ and $T_{3}$ levels, the total levels of these hormones were significantly increased after two weeks of HF diet-feeding. However, after eight weeks, only total $\mathrm{T}_{3}$ remained increased (Table 1).

Specific activity of D1 increased in both white fat depots in response to the HF diet, the strongest effect
( 3.4-fold induction) being on epididymal fat after eight weeks, while after two weeks, the stimulation was only observed in subcutaneous and not in epididymal fat (Table 1). On the other hand, the dietary treatment had no effect on specific D1 activity in interscapular brown fat (Table 1). In the liver, specific D1 activity was several orders of magnitude higher than in adipose tissue, and in line with the previous studies (Hartmann et al. 1980, Pavelka et al. 1997), it was stimulated by the HF diet (Table 1). Specific activity of D1 in white adipose tissue increased together with the size of adipocytes (Fig. 1A), as well as the plasma leptin level (Fig. 1B), suggesting correlative relations. Compared with D1, specific 
activities of both D2 and D3 in white fat depots were $\sim 50$-fold (epididymal fat) to $\sim 100$-fold (subcutaneous fat) lower and did not change in response to the HF diet (not shown).
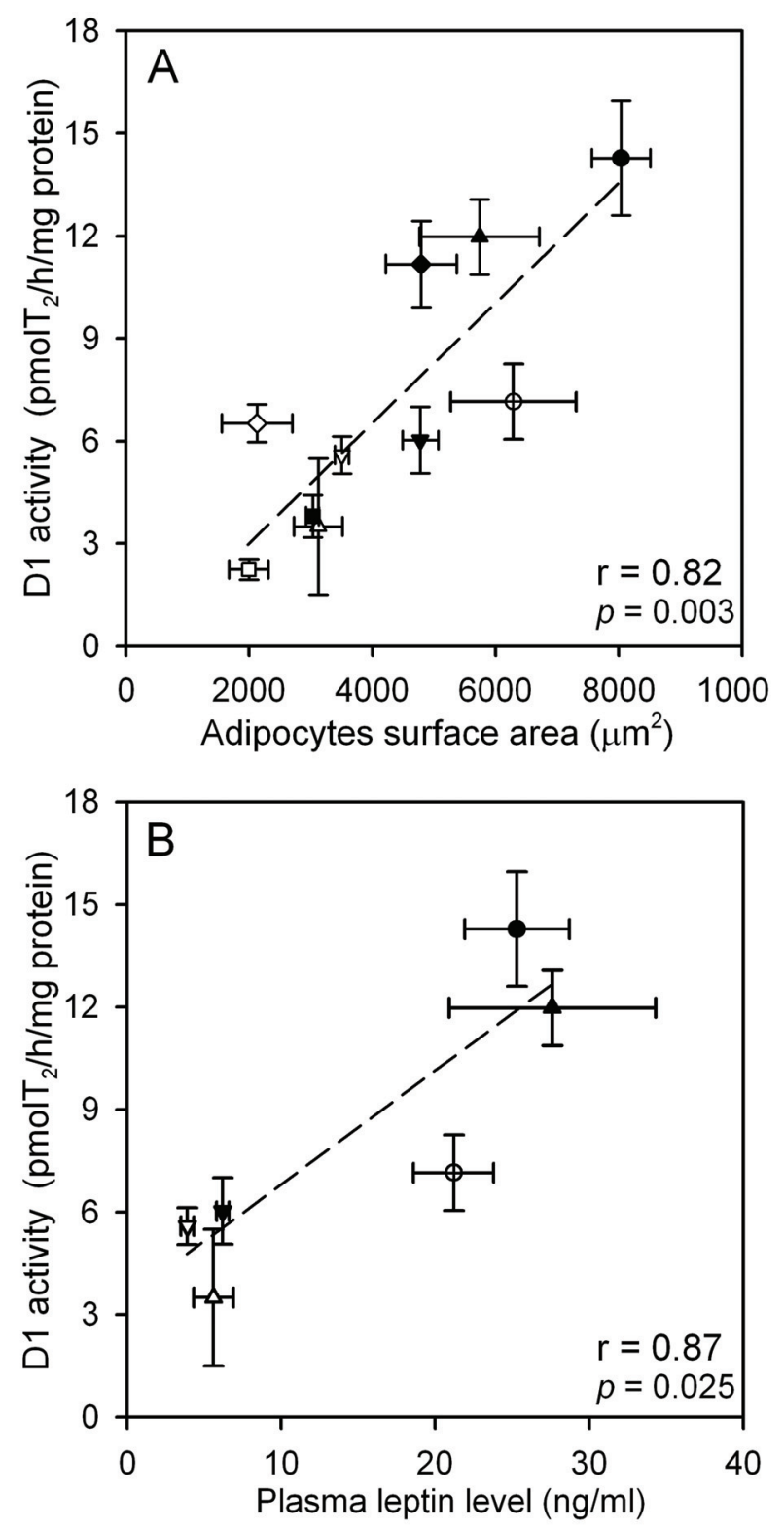

Fig. 1. A. Correlation of the white adipose tissue D1 activity (two weeks, $n=14-17$; eight weeks $n=3-8$ ) and surface area of adipocytes $(n=3-4)$. Epididymal fat at two (triangle down) and eight weeks (triangle up), and dorsolumbar fat at two (square) and eight weeks (diamond) from mice fed HF (black) or LF diet (white), following the obesogenic treatment protocol; epididymal fat from the HF-AL mice (black circle) and HF-CR mice (crossed circle), following the caloric restriction treatment protocol. B. Correlation of the white adipose tissue D1 activity (two weeks, $n=14-17$; eight weeks $n=3-8)$ and plasma leptin levels $(n=7-8)$. Epididymal fat at two (triangle down) and eight weeks (triangle up) from mice fed HF (black) or LF diet (white), following the obesogenic treatment protocol; epididymal fat from the HF-ALmice (black circle) and HF-CR-mice (crossed circle), following the caloric restriction treatment protocol. Data are means \pm S.E.M.; for original data, see Tables 1 and 2.
Table 2. Growth characteristics, adiposity, plasma levels of hormones, and D1 activity - caloric restriction.

\begin{tabular}{|c|c|c|}
\hline & HF-AL & HF-CR \\
\hline \multicolumn{3}{|l|}{ Body weight (g) } \\
\hline Initial & $28.3 \pm 0.6$ & $28.2 \pm 0.6$ \\
\hline Final & $35.9 \pm 0.9$ & $30.8 \pm 0.5^{* *}$ \\
\hline Gain & $7.6 \pm 0.4$ & $2.6 \pm 0.6^{* *}$ \\
\hline \multicolumn{3}{|c|}{ Weight of fat depots (mg) } \\
\hline$E P I$ & $1913 \pm 136$ & $1402 \pm 72 * *$ \\
\hline$D L$ & $679 \pm 45$ & $475 \pm 23 * *$ \\
\hline$B A T$ & $192 \pm 10$ & $139 \pm 5^{* *}$ \\
\hline \multicolumn{3}{|c|}{ Adipocytes surface area $\left(\mu m^{2}\right)$} \\
\hline$E P I$ & $8038 \pm 475$ & $6289 \pm 1015$ \\
\hline \multicolumn{3}{|l|}{ Plasma levels } \\
\hline Leptin $(n g / m l)$ & $25.3 \pm 3.4$ & $21.2 \pm 2.6^{*}$ \\
\hline total $T_{4}(\mathrm{nmol} / \mathrm{l})$ & $45.0 \pm 4.7$ & $54.6 \pm 6.5$ \\
\hline total $T_{3}(\mathrm{nmol} / \mathrm{l})$ & $1.75 \pm 0.08$ & $1.75 \pm 0.07$ \\
\hline free $T_{4}(\mathrm{pmol} / \mathrm{l})$ & $11.4 \pm 0.7$ & $11.6 \pm 0.7$ \\
\hline free $T_{3}(\mathrm{pmol} / \mathrm{l})$ & $3.46 \pm 0.18$ & $2.65 \pm 0.09 * *$ \\
\hline \multicolumn{3}{|c|}{ D1 activity (pmol $T_{2} / h / m g$ protein) } \\
\hline$E P I$ & $14.3 \pm 1.6$ & $7.2 \pm 1.1 * *$ \\
\hline Liver & $2566 \pm 281$ & $1946 \pm 202$ \\
\hline \multicolumn{3}{|c|}{ Transcript levels of the genes in EPI (AU) } \\
\hline Leptin & $6.1 \pm 0.4$ & $2.9 \pm 0.4 * *$ \\
\hline$S C D-1$ & $0.39 \pm 0.06$ & $0.75 \pm 0.03 * *$ \\
\hline
\end{tabular}

Mice were born and maintained at $22{ }^{\circ} \mathrm{C}$ and weaned to LF diet at four weeks of age. From the age of three months, all mice were fed HF diet for seven weeks, following the caloric restriction protocol. During the last five weeks of feeding on the HF diet, some mice were fed ad libitum (HF-AL) while some animals were calorie restricted by $10 \%$ (HF-CR). EPI - epididymal white fat, $D L$ - dorsolumbar subcutaneous white fat, $B A T$ - interscapular brown fat. Data are means \pm S.E.M. $(n=11-12)$. * $p<0.05$; $* * p<0.005$ for the effect of diet. The morphometry data are based on $>2400$ cells taken randomly from six different areas per animal $(n=4)$.

\section{Caloric restriction}

To find out whether the HF diet-induced elevation of D1 activity in white adipose tissue could be reversed when fat accumulation is compromised without changing the diet composition, a mild caloric restriction was applied in adult mice fed the HF diet. Due to low activities of D2 and D3 in white fat, and the lack of the activity changes in response to the obesogenic diet, D2 and D3 have not been studied any further. Compared with ad libitum fed HF-AL mice, a five-week-caloric restriction in HF-CR mice resulted in a reduction in body weight gain, a decrease in 

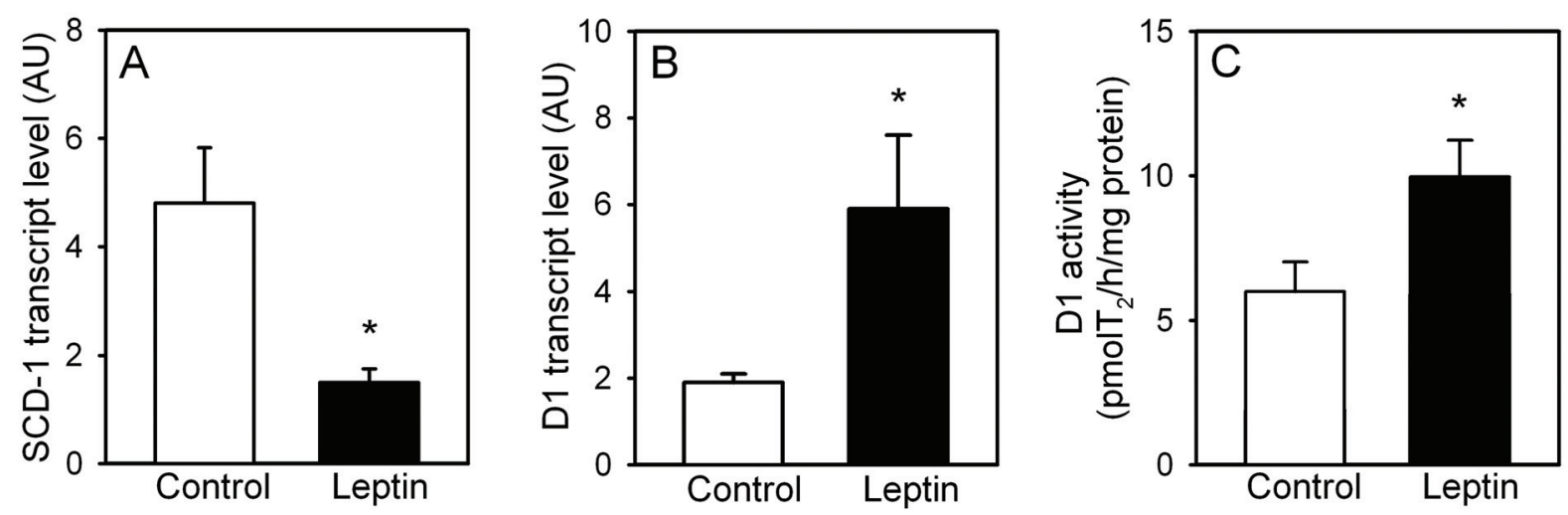

Fig. 2. Effect of leptin on gene expression $(\mathbf{A}, \mathbf{B})$ and $D 1$ activity $(\mathbf{C})$ in epididymal fat. At two weeks after weaning to LF diet, mice were injected with three doses $(3 \mathrm{mg} / \mathrm{kg}$ ) of leptin for three days and epididymal adipose tissue was dissected 16 hours after the last injection. Data are means \pm S.E.M $(n=4-5)$. ${ }^{*} p<0.05$ for the effect of leptin vs. saline-injected mice.

the weight of adipose tissue depots, and the reversal of adipocytes hypertrophy in epididymal fat pad (Table 2). In association with the changes in white fat content, plasma leptin levels and leptin gene expression in epididymal fat, were significantly reduced by caloric restriction. The HFCR mice had relatively low plasma levels of free $T_{3}$ (Table 2).

Compared with the HF-AL mice, the HF-CR mice exhibited $\sim 2.0$-fold lower specific activity of D1 in epididymal adipose tissue. Expression of the SCD-1 gene, a marker of the leptin metabolic effect (see Introduction), in epididymal adipose tissue increased in response to caloric restriction (Table 2). In contrast to adipose tissue, specific D1 activity in the liver was not significantly affected by caloric restriction (Table 2 ).

\section{Leptin treatment}

In line with the effect of leptin on some other tissues (Cabanelas et al. 2006, Araujo et al. 2009), the above results suggest that D1 activity in white fat could be increased by leptin secreted from hypertrophic adipocytes. To verify this hypothesis, mice weaned to the LF diet were repeatedly injected with leptin or saline two weeks after the weaning (see Methods). Expression of the SCD-1 gene, a marker of the leptin metabolic effect (see Introduction), as well as D1 gene transcript levels and D1 activity were evaluated in epididymal fat 16 hours after the last leptin injection. As expected, the expression of the SCD-1 gene was substantially, 3.2-fold, suppressed by leptin (Fig. 2A). In parallel, expression of D1 increased 3.1-fold (Fig. 2B) and D1 activity was elevated $\sim 1$.7-fold (Fig. 2 C).

\section{Discussion}

In experiments on mice, we have demonstrated for the first time that (i) the metabolism of $\mathrm{TH}$ in white adipose tissue was altered in association with physiological changes of fat mass and size of adipocytes; (ii) only D1, and not D2 and D3, was involved; and (iii) D1 was stimulated by leptin, which could explain the correlation between D1 activity and adiposity.

Specific activity of D1 in white fat depots correlated with both the size of adipocytes and leptin levels during HF diet-induced fat expansion, as well as during adipose tissue involution elicited by a mild caloric restriction of the HF diet-fed mice. D1 activity changed similarly in epididymal as well as in subcutaneous dorsolumbar fat pad during the HF diet feeding, although there was no difference between the LF and HF mice in epididymal fat D1 activity after two weeks of the dietary treatment. Our results suggest that D1 activity in adipose tissue, under physiological conditions, is modulated in an autocrine manner by leptin, produced in the tissue, rather than by circulating leptin. In support of this hypothesis, the activity of D1 correlated with the size of adipocytes in white fat, in line with the notion that leptin secretion increases with hypertrophy of white adipocytes (Skurk et al. 2007). Moreover, D1 activity in brown fat was not stimulated by $\mathrm{HF}$ diet, reflecting the fact that brown adipocytes do not secret leptin (Cinti et al. 1997). Given the existence of the autocrine modulation of D1 activity by leptin, this activity would be relatively insensitive to fluctuation of circulating leptin concentrations. Only large changes in the concentrations, e.g. the changes elicited by the administration of endogenous leptin, would affect the D1 activity. Changes in leptin sensitivity, such as leptin-resistance associated with obesity, would probably also affect modulation of D1 activity by leptin.

With respect to the known responses of the 
thyroid system to dietary manipulations, the mice reacted quite normally. Thus, HF diet-feeding resulted in increased plasma levels of total $\mathrm{T}_{3}$, as typically found under conditions of overnutrition (Danforth et al. 1979) and obesity in euthyroid subjects (Michalaki et al. 2006, De Pergola et al. 2007), and activity of liver D1 also significantly increased after the feeding (Hartmann et al. 1980). As also expected, plasma free $T_{3}$ and leptin levels decreased in response to caloric restriction (Kok et al. 2005, Larson-Meyer et al. 2006, Araujo et al. 2009a). That hepatic D1 activity did not decrease could reflect the fact that a very mild (only $10 \%$ ) caloric restriction was applied (Araujo et al. 2009). Importantly, in contrast to the liver, activity of D1 in the epididymal adipose tissue decreased significantly due to caloric restriction, again supporting the role of locally produced leptin in the control of D1 activity in adipose tissue (see above).

The fact that leptin stimulated D1 activity in white fat is in accordance with the leptin action in some other tissues, such as the liver, pituitary and thyroid gland (Cabanelas et al. 2006, Araujo et al. 2009). Regarding the broad range of substrates metabolized by D1 with only $\mathrm{T}_{3}$ representing a well established biologically active product of the deiodination reaction (see Introduction), the physiological role for D1 in white fat remains to be established. In this respect, several possibilities may be explored. First, the relatively strong response of the adipose tissue D1 activity to leptin, which was associated with the downregulation of SCD-1, suggests that $T_{3}$ formed by D1 may be involved in the modulation of metabolism of white adipose tissue by leptin. SCD-1 has a key role in the regulation of lipid metabolism (Cohen and Friedman 2004, Paton and Ntambi 2008), including induction of fatty acid oxidation by leptin in white fat (Zhang et al. 2008) and the liver (Kakuma et al. 2002, Cohen and Friedman 2004, Biddinger et al. 2006). The mechanism by which leptin decreases expression of SCD-1 is independent of known prolipogenic factors, insulin and sterol regulatory element-binding protein-1c
(Biddinger et al. 2006), and it remains to be specified (Cohen and Friedman 2004, Biddinger et al. 2006). Importantly, hepatic SCD-1 gene expression could be down-regulated by $\mathrm{T}_{3}$, reflecting the presence of a negative $T_{3}$ response region in the SCD-1 gene promoter (Waters et al. 1997). Therefore, in both the liver and white fat, leptin-induced downregulation of SCD-1 expression may result from the stimulation of D1 activity by leptin and subsequent suppression of SCD-1 genepromoter activity by locally produced $\mathrm{T}_{3}$. Secondly, D1-generated $T_{3}$ could be involved in the induction of angiogenesis in white adipose tissue, through $\mathrm{T}_{3}$-dependent activation of hypoxia-inducible factor-1 controlling transcription of the angiogenic genes (Otto et al. 2009). Thirdly, $\mathrm{T}_{3}$ generated by $\mathrm{D} 1$ in white adipose tissue could also interact with thyroid hormone receptor TR $\alpha 1$ in the tissue and thereby modulate subcutaneous adipose tissue expandability (Ortega et al. 2009).

In conclusion, our results demonstrate for the first time the changes in D1 activity in white adipose tissue under the conditions of changing adiposity, and a stimulatory effect of leptin on D1 activity in white adipose tissue. Our results suggest that D1 has a functional role in white adipose tissue with D1 possibly being involved in the control of adipose tissue metabolism and/or accumulation of the tissue.

\section{Conflict of Interest}

There is no conflict of interest.

\section{Acknowledgements}

The authors thank K. Bohunová and V. Mihálová for their technical assistance, and M. Bryhn and M. Rossmeisl for critical reading of the manuscript. This work was supported by the Czech Science Foundation (305/08/H037), COST Action BMB0602 (OC08007), research project AV0Z50110509 and MSM0021622413, and EPAX AS (Norway).

\section{References}

ARAUJO RL, ANDRADE BM, DA SILVA ML, FERREIRA AC, CARVALHO DP: Tissue-specific deiodinase regulation during food restriction and low replacement dose of leptin in rats. Am J Physiol 296: E1157-E1163, 2009.

BIANCO AC, SALVATORE D, GEREBEN B, BERRY MJ, LARSEN PR: Biochemistry, cellular and molecular biology and physiological roles of the iodothyronine selenodeiodinases. Endocr Rev 23: 38-89, 2002. 
BIDDINGER SB, MIYAZAKI M, BOUCHER J, NTAMBI JM, KAHN CR: Leptin suppresses stearoyl-coa desaturase 1 by mechanisms independent of insulin and sterol regulatory element-binding protein-1c. Diabetes 55: 2032 2041, 2006.

CABANELAS A, LISBOA PC, MOURA EG, PAZOS-MOURA CC: Leptin acute modulation of the 5'-deiodinase activities in hypothalamus, pituitary and brown adipose tissue of fed rats. Horm Metab Res 38: 481-485, 2006.

CINTI S: The Adipose Tissue. Editrice Kurtis s.r.l., Milano, Italy, 1999.

CINTI S, FREDERICH RC, ZINGARETTI MC, DE MATTEIS R, FLIER JS, LOWELL BB: Immunohistochemical localization of leptin and uncoupling protein in white and brown adipose tissue. Endocrinology 138: 797-804, 1997.

COHEN P, FRIEDMAN JM: Leptin and the control of metabolism: role for stearoyl-coa desaturase-1 (scd-1). J Nutr 134: 2455S-2463S, 2004.

DANFORTH E JR, HORTON ES, O'CONNELL M, SIMS EA, BURGER AG, INGBAR SH, BRAVERMAN L, VAGENAKIS AG: Dietary-induced alterations in thyroid hormone metabolism during overnutrition. $J$ Clin Invest 64: 1336-1347, 1979.

De PERGola G, CiAMPOLILlo A, PAOLOTTI S, TREROTOLI P, GIORGINO R: Free triiodothyronine and thyroid stimulating hormone are directly associated with waist circumference, independently of insulin resistance, metabolic parameters and blood pressure in overweight and obese women. Clin Endocrinol (Oxf) 67: 265-269, 2007.

GALTON VA, SCHNEIDER MJ, CLARK AS, GERMAIN DL: Life without thyroxine to 3,5,3'-triiodothyronine conversion: studies in mice devoid of the 5'-deiodinases. Endocrinology 150: 2957-2963, 2009.

HARTMANN K, WEBER A, HARTMANN N: Liver deiodase activity in rats of different body weight and fat contents following high or low fat diet. Comparison of enzymatic deiodination with T4-clearance rate and thyroid activity in animals. Endokrinologie 75: 357-364, 1980.

KAKUMA T, LEE Y, UNGER RH: Effects of leptin, troglitazone, and dietary fat on stearoyl CoA desaturase. Biochem Biophys Res Commun 297: 1259-1263, 2002.

KOK P, ROELFSEMA F, LANGENDONK JG, FROLICH M, BURGGRAAF J, MEINDERS AE, PIJL H: High circulating thyrotropin levels in obese women are reduced after body weight loss induced by caloric restriction. J Clin Endocrinol Metab 90: 4659-4663, 2005.

KOPECKÝ J, ROSSMEISL M, FLACHS P, BRAUNER P, ŠPONAROVÁ J, MATĚJKOVÁ O, PRAŽÁK T, RŮŽIČKOVÁ J, BARDOVÁ K, KUDA O: Energy metabolism of adipose tissue-physiological aspects and target in obesity treatment. Physiol Res 53 (Suppl 1): S225-S232, 2004.

KOPECKÝ J, SIGURDSON L, PARK IR, HIMMS-HAGEN J: Thyroxine 5'-deiodinase in hamster and rat brown adipose tissue: effect of cold and diet. Am J Physiol 251: E1-E7, 1986.

KUDA O, JELENÍK T, JÍLKOVÁ Z, FLACHS P, ROSSMEISL M, HENSLER M, KAZDOVÁ L, OGSTON N, BARANOWSKI M, GORSKI J, JANOVSKÁ P, KŮS V, POLÁK J, MOHAMED-ALI V, BURCELIN R, CINTI S, BRYHN M, KOPECKÝ J: n-3 fatty acids and rosiglitazone improve insulin sensitivity through additive stimulatory effects on muscle glycogen synthesis in mice fed a high-fat diet. Diabetologia 52: 941951, 2009.

KƯS V, PRAŽÁK T, BRAUNER P, HENSLER M, KUDA O, FLACHS P, JANOVSKÁ P, MEDRIKOVÁ D, ROSSMEISL M, JÍLKOVÁ Z, ŠTEFL B, PAŠŤÁLKOVÁ E, DRAHOTA Z, HOUŠTĚK J, KOPECKÝ J: Induction of muscle thermogenesis by high-fat diet in mice: association with obesity-resistance. Am J Physiol 295: E356-E367, 2008.

LARSON-MEYER DE, HEILBRONN LK, REDMAN LM, NEWCOMER BR, FRISARD MI, ANTON S, SMITH SR, ALFONSO A, RAVUSSIN E: Effect of calorie restriction with or without exercise on insulin sensitivity, beta-cell function, fat cell size, and ectopic lipid in overweight subjects. Diabetes Care 29: 1337-1344, 2006.

LEONARD JL, MELLEN SA, LARSEN PR: Thyroxine 5'-deiodinase activity in brown adipose tissue. Endocrinology 112: 1153-1155, 1983.

MICHALAKI MA, VAGENAKIS AG, LEONARDOU AS, ARGENTOU MN, HABEOS IG, MAKRI MG, PSYROGIANNIS AI, KALFARENTZOS FE, KYRIAZOPOULOU VE: Thyroid function in humans with morbid obesity. Thyroid 16: 73-78, 2006. 
MINOKOSHI Y, KIM YB, PERONI OD, FRYER LG, MULLER C, CARLING D, KAHN BB: Leptin stimulates fatty-acid oxidation by activating amp-activated protein kinase. Nature 415: 339-343, 2002.

OBREGON MJ: Thyroid hormone and adipocyte differentiation. Thyroid 18: 185-195, 2008.

OPPENHEIMER JH, SCHWARTZ HL, LANE JT, THOMPSON MP: Functional relationship of thyroid hormoneinduced lipogenesis, lipolysis, and thermogenesis in the rat. J Clin Invest 87: 125-132, 1991.

ORCI L, COOK WS, RAVAZZOLA M, WANG MY, PARK BH, MONTESANO R, UNGER RH: Rapid transformation of white adipocytes into fat-oxidizing machines. Proc Natl Acad Sci USA 101: 2058-2063, 2004.

ORTEGA FJ, MORENO-NAVARRETE JM, RIBAS V, ESTEVE E, RODRIGUEZ-HERMOSA JI, RUIZ B, PERAL B, RICART W, ZORZANO A, FERNANDEZ-REAL JM: Subcutaneous fat shows higher thyroid hormone receptor-alpha1 gene expression than omental fat. Obesity 17: 2134-2141, 2009.

OTTO T, FANDREY J: Thyroid hormone induces Hypoxia-inducible factor $1 \alpha$ gene expression through thyroid hormone receptor $\beta /$ Retinoid $\mathrm{X}$ receptor $\alpha$-dependent activation of hepatic leukemia factor. Endocrinology 149: 2241-2250, 2009.

PATON CM, NTAMBI JM: Biochemical and physiological function of stearoyl-CoA desaturase. Am J Physiol 297: E28-E37, 2009.

PAVELKA S, KOPECKÝ P, BENDLOVÁ B, ŠTOLBA P, VÍTKOVÁ I, VOBRUBA V, PLÁVKA R, HOUŠTĚK J, KOPECKÝ J: Tissue metabolism and plasma levels of thyroid hormones in critically ill very premature infants. Pediatr Res 42: 812-818, 1997.

RŮŽIČKOVÁ J, ROSSMEISL M, PRAŽÁK T, FLACHS P, ŠPONAROVÁ J, VECKA M, TVRZICKÁ E, BRYHN M, KOPECKÝ J: Omega-3 PUFA of marine origin limit diet-induced obesity in mice by reducing cellularity of adipose tissue. Lipids 39: 1177-1185, 2004.

SILVA JE: Thermogenic mechanisms and their hormonal regulation. Physiol Rev 86: 435-464, 2006.

SKURK T, ALBERTI-HUBER C, HERDER C, HAUNER H: Relationship between adipocyte size and adipokine expression and secretion. J Clin Endocrinol Metab. 92: 1023-1033, 2007.

SURWIT RS, FEINGLOS MN, RODIN J, SUTHERLAND A, PETRO AE, OPARA EC, KUHN CM, REBUFFESCRIVE M: Differential effects of fat and sucrose on the development of obesity and diabetes in C57Bl/6J and A/J mice. Metabolism 44: 645-651, 1995.

WANG JL, CHINOOKOSWONG N, YIN S, SHI ZQ: Calorigenic actions of leptin are additive to, but not dependent on, those of thyroid hormones. Am J Physiol 279: E1278-E1285, 2000.

WATERS KM, MILLER CW, NTAMBI JM: Localization of a negative thyroid hormone-response region in hepatic stearoyl-coa desaturase gene 1. Biochem Biophys Res Commun 233: 838-843, 1997.

YEN PM: Physiological and molecular basis of thyroid hormone action. Physiol Rev 81: 1097-1142, 2001.

ZHANG W, DELLA-FERA MA, HARTZELL DL, HAUSMAN D, BAILE CA: Adipose tissue gene expression profiles in ob/ob mice treated with leptin. Life Sci 83: 35-42, 2008.

ZHANG Y, PROENCA R, MAFFEI M, BARONE M, LEOPOLD L, FRIEDMAN JM: Positional cloning of the mouse obese gene and its human homologue. Nature 372: 425-432, 1994. 